\title{
Modelling of Urban Growth and Planning: A Critical Review
}

\author{
Marwa Ibrahim Hassan1, Sami Mustafa M. Elhassan² \\ ${ }^{1}$ Ministry of Physical Planning and Urban Development, Khartoum, Sudan \\ ${ }^{2}$ UTP Universiti Teknologi PETRONAS, Perak, Malaysia \\ Email: m3moon1986@gmail.com,sami.mustafa@utp.edu.my
}

How to cite this paper: Hassan, M.I. and Elhassan, S.M.M. (2020) Modelling of Urban Growth and Planning: A Critical Review. Journal of Building Construction and Planning Research, 8, 245-262. https://doi.org/10.4236/jbcpr.2020.84016

Received: September 29, 2020

Accepted: December 6, 2020

Published: December 9, 2020

Copyright $\odot 2020$ by author(s) and Scientific Research Publishing Inc. This work is licensed under the Creative Commons Attribution International License (CC BY 4.0).

http://creativecommons.org/licenses/by/4.0/

(c) (i) Open Access

\begin{abstract}
For thousands of years, cities have been the center of civilization. According to that, detecting, monitoring and controlling urban growth became the most urgent need in urban planning and urban development process to get the expected results that can build a concrete base for decision makers to drive the polices toward best track. The issue of this paper is about urban growth and planning models and techniques such as geographic information system (GIS), cellular automata (CA), genetic algorithm (GA), regression model (R model) and etc. The main objective of this paper is to summarize the 70 scientific papers concern about urban growth to make a review and find out the most important objective, factors, techniques and results for best approach to studying urban growth. The criteria of choosing the papers are that each paper should focus mainly on urban growth modeling and techniques, also, using wide variety of data and factors. This paper aims to fill the gap of absence of the best methods for studying urban growth, as there is a diversity in the methods used, and there is also an absence of exemplary methods or optimal methods for using analytical tools to study urban growth. So, this paper tries to make it easy for researcher to mix the suitable techniques to get acceptable result for their hypothesis. The results assert combining two or more than two techniques and model to assure that the simulation or prediction models can give real and right approaches. However, most researches focused on combining specific techniques with models such as Cellular Automata CA-Markov Chain MC Model-Logistic regression or Cellular Automata CA-Markov Chain MC model or GIS-MCDM or GIS Based AHP etc. Although, in many references some of these techniques were combined together to extract best result. However, the rule that defines the best combination relies on project criteria, the infinite factors, analysis tools, the nature and quality of these models. On the other hand, whether the project needs a simulation or prediction models, all these models can achieve better result
\end{abstract}


when integrated with quantitative models such as analytic hierarchy process (AHP), the Markov chain analysis or multi-criteria decision making (MCDM) techniques. Also, using remote sensing, satellite images and land use and land cover maps as basic data for analysis were the most common factors according to this review.

\section{Keywords}

Geographic Information System (GIS), Cellular Automata (CA), Markov Chain (MC), Remote Sensing (RS), Analytical Hierarchy Process (AHP)

\section{Introduction}

Urbanization refers to a form of paved surface growth in response to increasing human activities with implications of economic, social, and political forces and to the physical geography of an area [1]. While urbanization has been long recognized as a fundamental element of the process of economic development, sustainable urbanization has become one of the main and more pressing challenges for developing countries. Millions live in these countries lacking adequate access to basic services like electricity, clean water and sanitation [2]. Rapid urbanization combined with a spiraling population growth in the cities of developing nations creates land resource demands which lead to serious environmental issues. Urban development is characterized by drastic land use and land cover changes, rooted in urban population growth, with concomitant anthropogenic stressors contributing to global climate changes [3]. A better understanding of the urban growth process and its effect on the environment is essential for efficient urban management. Urban modeling has emerged as part of the effort to quantify the growth process based on scientific principles [4].

Evaluation of plan implementation is important because it reflects the extent to which a plan succeeds in predicting, guiding, and controlling future urban development. One common way to determine what a plan has accomplished is to measure the conformance degree between the actual outcomes or impacts and the proposed plans. By doing so, planners can acquire insights on how the planning decision-making process operates and validate whether planning efforts do contribute to goal achievement [5].

This paper provides a critical review for previous studies on modelling of urban planning and controlling. Also, it discusses the factors considered in each of these studies, how the researchers deal with these factors and the final results. This paper aims to help researchers and practitioners in their way towards achieving results and solutions for urban growth problems. This paper discusses a major problem which is the absence of the best methods for studying urban growth, as there is a diversity in the methods used, but there is also an absence of exemplary methods or optimal methods for using analytical tools to study urban growth. Also, pursuing to answer important questions such as: What are the best 
practices nowadays to control or to predict urban growth? And what are the most important results that could be useful for urban planner to control urban growth, and finally to what extent each of these models could be able to work with each other to give the researchers the objective results. The importance of this study comes from the time wasted to find the best practice to manage urban growth among all these choices of techniques and models. So, this research aimed to find best techniques combination of urban growth problems. The structure of this paper depends on summarizing and extracting the most important information to form the best practice and best approach to study urban growth modelling and planning as represented by Figure 1 .

\section{Urban Growth Literature Review}

\section{Countries and Techniques}

Following the literature, and according to references [1]-[70] some countries focus on urban planning growth compare to other countries as represented by Figure 2. According to Figure 2 a country as China is obviously concerned about urban growth development issues followed by India, the USA and Iran. These Asian countries have high rate of population growth or urbanization growth. So, finding the most useful way to predict and manage this growth was the main reason to make all these researches on this topic. In addition to that, $19 \%$ of other countries from the 70 scientific papers give the topic of urban growth a concrete research to solve critical problems. Overall view, if all these countries put this topic as a basic topic to research that's means making acritical review on urban growth is just another step on the right track.

Referring to Figure 3, and according to references [1]-[70] researchers mostly prefer to use remote sensing and satellite images, regression model, GIS and CA model for studying urban growth issues. Moreover, using SA, MC and GEOMOND model also took much concern mainly by combining these models together or

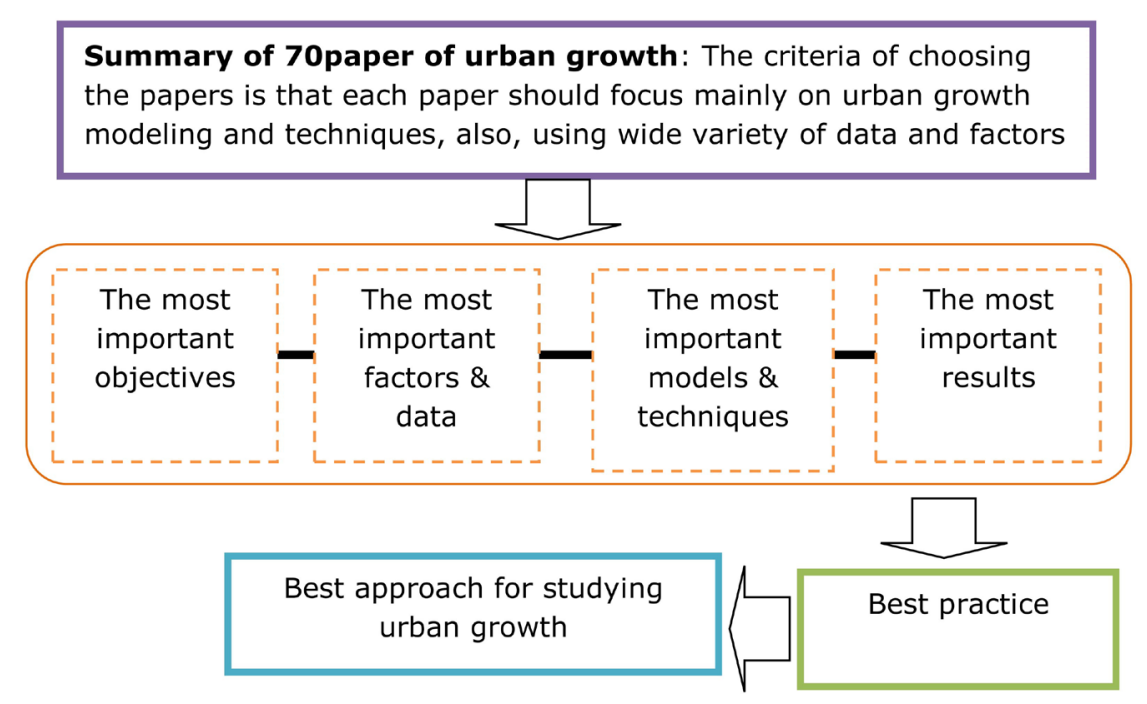

Figure 1. Illustrate study structure. 


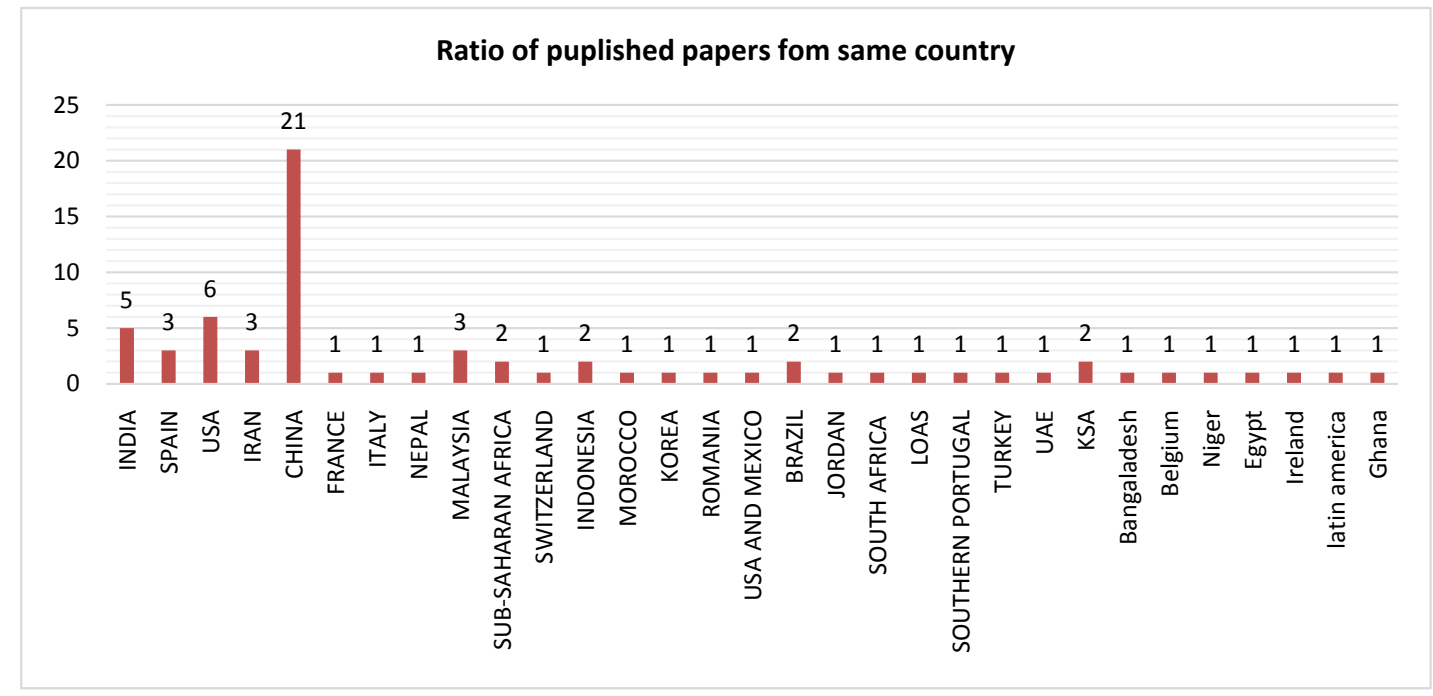

Figure 2. Published papers ratios from same country on urban growth subject.

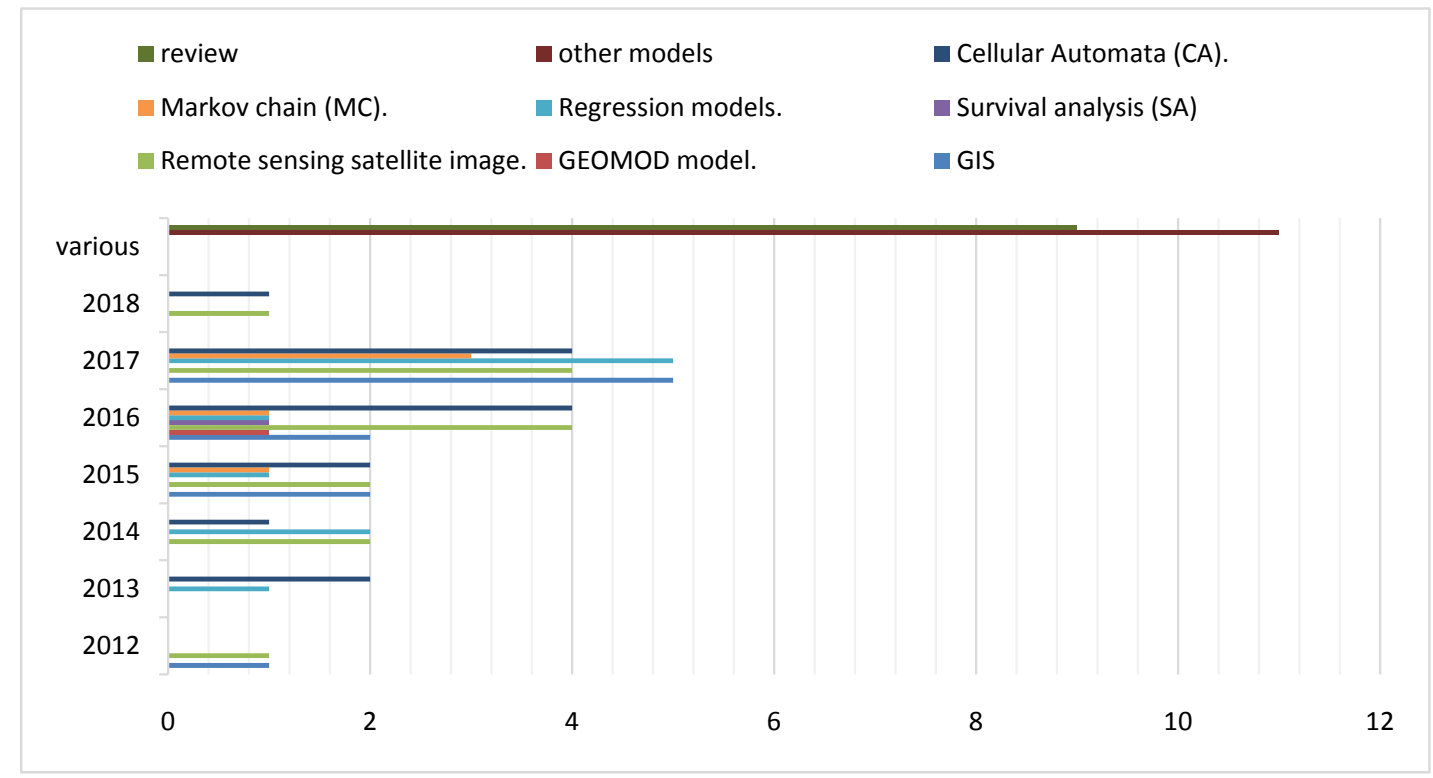

Figure 3. The most important used repetitively models and techniques for studying urban growth.

with other models or techniques. In addition to that, during 2016 and 2017 these models rise as a reasonable tool to estimate or to simulate and predict urban growth. All in all, using those models is such an essential and fundamental part to build a concrete management plan for urban growth.

\section{The Most Important Factors and Data}

By reviewing the literature and references [1]-[70], there are some important and specific data used for urban growth with simulating and predicting models as showing by Table 1 . Land use and land cover change maps mainly used for the majority of simulation and prediction model followed mainly by geospatial data set and land use index. But obviously, there are some set of data that must 
Table 1. The most important data used repetitively for urban growth with simulating and predicting models.

\begin{tabular}{|c|c|c|c|c|c|c|c|c|c|c|c|c|c|c|c|}
\hline $\begin{array}{l}\quad \text { Types of data } \\
\text { Simulating } \\
\text { And } \\
\text { Predicting } \\
\text { models }\end{array}$ & 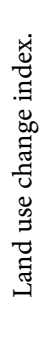 & 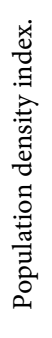 & 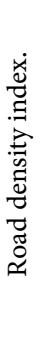 & 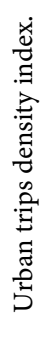 & 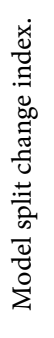 & 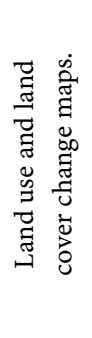 & 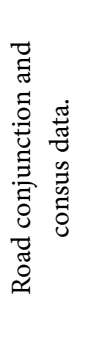 & 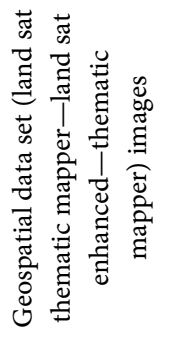 & 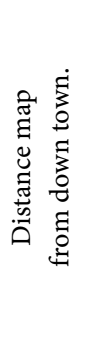 & 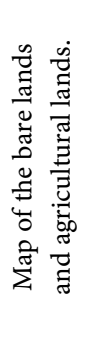 & 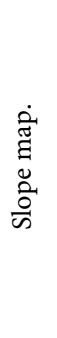 & 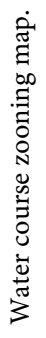 & 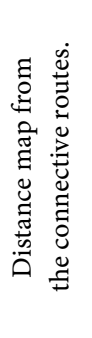 & 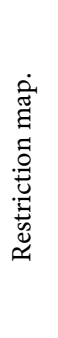 & 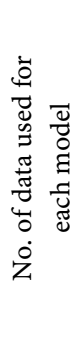 \\
\hline GIS & $\checkmark$ & $\checkmark$ & $\checkmark$ & $\checkmark$ & $\checkmark$ & $\checkmark$ & $\checkmark$ & & & & & & & & 7 \\
\hline CA & & & & & & $\checkmark$ & & $\checkmark$ & & & & & & & 2 \\
\hline GEOMOD model & & & & & & & & & $\sqrt{ }$ & $\sqrt{ }$ & $\checkmark$ & $\checkmark$ & $\checkmark$ & $\checkmark$ & 6 \\
\hline $\mathrm{MC}$ & $\checkmark$ & & & & & $\checkmark$ & & $\checkmark$ & & & & & & & 2 \\
\hline $\begin{array}{l}\text { Remote sensing (RS) } \\
\text { and satellite images }\end{array}$ & $\checkmark$ & $\checkmark$ & $\checkmark$ & $\checkmark$ & $\checkmark$ & $\checkmark$ & & $\checkmark$ & & $\checkmark$ & $\checkmark$ & & & & 9 \\
\hline $\begin{array}{l}\text { No. of models used for } \\
\text { each type of data }\end{array}$ & 3 & 2 & 2 & 2 & 2 & 4 & 1 & 3 & 1 & 2 & 2 & 1 & 1 & 1 & \\
\hline
\end{tabular}

be integrated together to get a better result such as using land use and land cover change maps or index, Model split change index, Urban trips density index, Road density index, Road conjunction and census data and Population density index as a fundamental data with GIS. Also, data as Distance map from down town, Map of the bare lands and agricultural lands, Slope map, Water course zooning map, Distance map from the connective routes and Restriction map advised to be used with GEOMOND Model. Added to that, all GIS data mentioned before and Geospatial data set (land sat thematic mapper-land sat enhanced - thematic mapper) images, Map of the bare lands and agricultural lands and Slope map were used with Remote sensing(RS) and satellite images. Overall, using a specific model demand knowing which data set must be used to get the ultimate result.

In addition to that, and by studying the literature from references [1]-[70] some factors have been used for urban growth with simulating and predicting models more than other factors as represented by Table 2. Value of urban expansion pattern takes place in most researches and as main factors for most models, followed by the factor of intersection between the buffer zone and the spots or between the buffer zone and the empty areas. Also, land use and land cover change, probability of: (organic growth-spontaneous growth-new spreading center) and Land use and land cover change were used with a specific model. Furthermore, MC Model, remote sensing (RS) and satellite images were used more data combination to get results. Overall view, knowing which data should use mainly or specifically with which model properly to lead to a reasonable and accurate result.

\section{Urban Growth Objectives and Techniques}

One of the critical issues in urban planning is the determination of appropriate 
Table 2. The most important factors used repetitively for urban growth with simulating and predicting models.

\begin{tabular}{|c|c|c|c|c|c|c|c|c|c|c|c|}
\hline $\begin{array}{l}\text { Types of data } \\
\text { Simulating } \\
\text { And } \\
\text { predicting models }\end{array}$ & 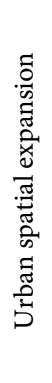 & 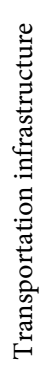 & 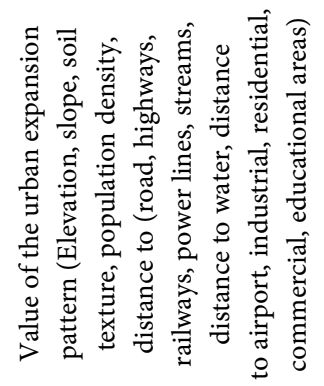 & 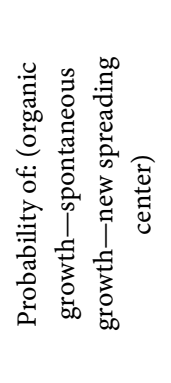 & 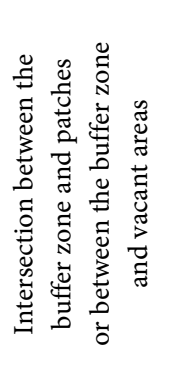 & 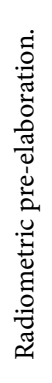 & 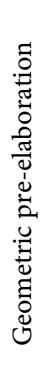 & 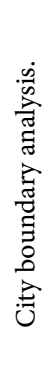 & 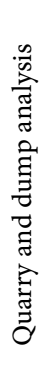 & 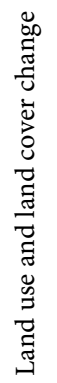 & 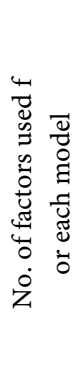 \\
\hline GIS & $\checkmark$ & $\checkmark$ & $\sqrt{ }$ & & & & & & & & 3 \\
\hline $\mathrm{CA}$ & & & $\checkmark$ & $\checkmark$ & $\checkmark$ & & & & & & 3 \\
\hline GEOMOD model & & & & & & & & & & $\checkmark$ & 1 \\
\hline $\mathrm{MC}$ & & & $\checkmark$ & $\checkmark$ & $\checkmark$ & $\checkmark$ & $\checkmark$ & $\checkmark$ & $\checkmark$ & $\checkmark$ & 8 \\
\hline SA & & & $\checkmark$ & $\checkmark$ & $\checkmark$ & & & & & & 3 \\
\hline $\begin{array}{l}\text { Remote sensing }(\mathrm{RS}) \text { and } \\
\text { satellite images }\end{array}$ & $\checkmark$ & $\checkmark$ & $\checkmark$ & & & $\checkmark$ & $\checkmark$ & $\checkmark$ & $\checkmark$ & $\checkmark$ & 8 \\
\hline $\begin{array}{l}\text { No. of models used for } \\
\text { each type of factors }\end{array}$ & 2 & 2 & 5 & 3 & 3 & 2 & 2 & 2 & 2 & 3 & \\
\hline
\end{tabular}

locations for urban growth in marginal areas adjacent to large-scale development [6]. Understanding trends in urban growth is crucial to realize sustainable development. In recent years, different studies have quantitatively modeled the spatiotemporal changes in different land uses and have provided guidance for urban sustainable management [7]. Among these studies, the empirical estimation method and dynamic simulation are two major approaches used during the past two decades for predictive land use modeling. Empirical estimation models use statistical methods to create a probability map to capture the complexity of LUC in the real world and identify the contributions of explanatory variables based on historical data [7].

\section{Models Integration}

As the subjects and objectives differ, the used models and models integration follow. Referring to Table 3 and according to mentioned references, CA model, GIS program, RS, MC model and regression model are the most used model to analyze urban growth. Obviously, some of the model work together very well such as CA-MC or GIS-regression analysis or CA-MC-AHP, GIS-RS, CA-RS-MC-(RT or LR), GIS-MC-RS, all these models integrations developed to get better result. Most researches depend basically on GIS, CA model, RS, satellite images and regression models to predict or simulate urban growth. Also, land cover/use change model worked basically with GIS and CA and regression models.

Moreover, using regression models take a fundamental part to predict or simulate urban growth. According to Table 4 and references [1]-[70], using regression models as a technique demand definite type of data and factors. These 
Table 3. The most important models and techniques worked together repetitively for simulating and predicting urban growth patterns.

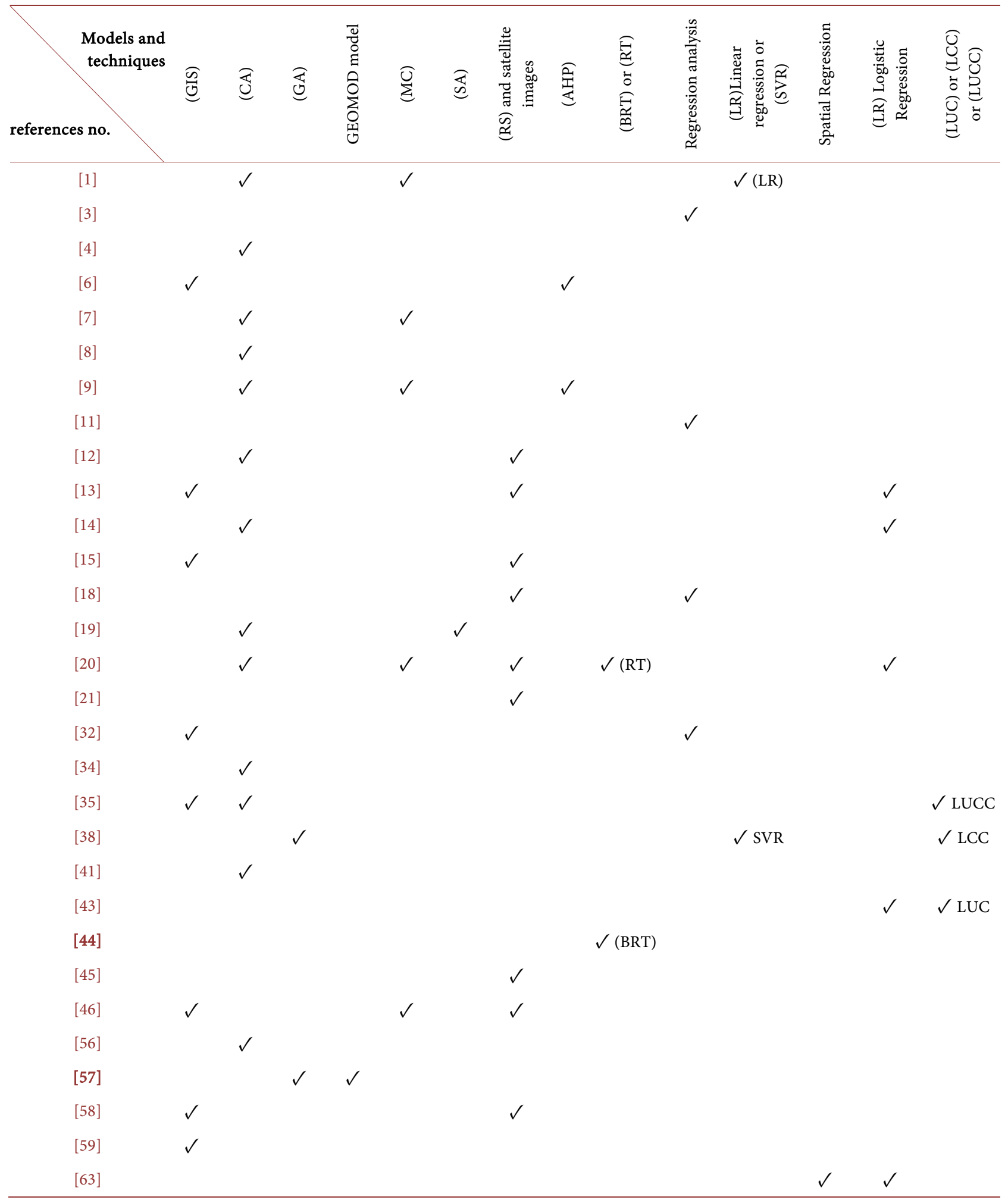

Note: these models can have combined with many other models but here we focus on the most important model and techniques. (GIS) Geographic information system, (CA) Cellular Automata, (GA) genetic algorithm, (MC) Markov chain, (SA) Survival analysis, (RS) Remote sensing, (AHP) Analytical Hierarchy Process, (BRT) Boosted regression trees, (RT) regression trees, (LR) Linear regression, (SVR) support vector regression, (LR) Logistic Regression, (LUC) land use/cover maps, (LCC) land cover change model, (LUCC) land use/cover change model. 
Table 4. The most important regression models factors used repetitively for simulating and predicting urban growth patterns.

\begin{tabular}{|c|c|c|c|}
\hline \multicolumn{4}{|c|}{ Regression models types } \\
\hline $\begin{array}{c}\text { Boosted regression } \\
\text { trees (BRT) }\end{array}$ & Regression analysis & Linear regression & Spatial Regression \\
\hline \multicolumn{4}{|c|}{ Factors and data } \\
\hline $\begin{array}{l}\text { - Transportation network } \\
\text { - Special interactions in the } \\
\text { form of neighborhood } \\
\text { indices. } \\
\text { - The topography } \\
\text { - Access } \\
\text { - Slope. } \\
\text { - Disturb. } \\
\text { - Urban map }\end{array}$ & $\begin{array}{l}\text { - City size. } \\
\text { - Transportation cost. } \\
\text { - State capital dummy } \\
\text { - Health care } \\
\text { - Climate } \\
\text { - Initial schooling public } \\
\text { - services. } \\
\text { - Density-land use and } \\
\text { land cover change } \\
\text { - Land transactions } \\
\text { - Road junctions- } \\
\text { population change }\end{array}$ & $\begin{array}{l}\text { Demographical and } \\
\text { annual average air } \\
\text { temperature data. }\end{array}$ & $\begin{array}{l}\text { - Patch density } \\
\text { - Land scape shape } \\
\text { index. } \\
\text { - } \text { Aggregation index } \\
\text { - } \text { Total area } \\
\text { - } \text { A multi temporal } \\
\text { land sat TM/ETM } \\
\text { imagery time series, } \\
\text { data set coverage. }\end{array}$ \\
\hline
\end{tabular}

data and factors should have connected to land use/change maps, density, urban maps geographical maps and census data. But, all these depend on research topic and objectives. Using quantitative techniques such as regression models, these studies helped identify the effects of particular variables (e.g. planning and political elements like UGBs, built environments, and socioeconomic attributes) on urban expansion or land development. Ideally, one could look into the land use data to examine the land use changes [5].

\subsection{Cellular Automata (CA) Model}

Cellular automata (CA) have been extensively employed to model urban growth since Tobler first applied this concept to geographic modeling. These dynamic changes are influenced by natural and socio-economic factors and their interactions on different spatio-temporal scales. Given that CA can use simple rules to simulate complicated spatio-temporal dynamic processes and can be easily integrated with high-resolution images and geographical information systems, CA and CA-based models have shown immense potential in simulating urban growth in the past years [8].

\subsection{GIS-MCDM}

GIS techniques have become a significant tool for controlling and monitoring changes in urban development and their impact on ecosystems. Land suitability analysis based on GIS environments is a process that aims to identify the best locations of development while considering environmental sustainability. In setting the importance of the criteria used and computing the weights of factors, GIS tools must be integrated with other methods to improve the results of land suitability analysis. The integration of GIS tools and multi-criteria decision 
analysis is a powerful approach for evaluating land suitability. The concept of sustainability generally leads to improved suitability analysis, which is a complex operation due to various types of factors and criteria that must be considered in the process [6].

\subsection{GIS Based AHP}

Previous studies and expert opinions were used to identify the significant factors that influence the determination of appropriate sites for urban growth. For suitability analysis using GIS-AHP, it is important to assign scores to each of the factors based on their suitability for urban growth. For suitability analysis using GIS-AHP, it is important to assign scores to each of the factors based on their suitability for urban growth. To do this, a pairwise comparison matrix using Saaty's nine-level scale for identifying relative weights was used. The calculation of factor weights was applied after the formation of the pairwise comparison matrix. The next step involves the computation of Consistency Ratio (CR), which is used to measure the consistency between the experts' opinions. The acceptable Consistency Ratio (CR) should be $\mathrm{CR}<0.10$, which refers to a reasonable level of consistency in the pairwise comparisons. In contrast, $C R>0.10$ refers to ratio values that are indicative of inconsistent judgments [6].

\subsection{GIS Based AHP}

Previous studies and expert opinions were used to identify the significant factors that influence the determination of appropriate sites for urban growth. For suitability analysis using GIS-AHP, it is important to assign scores to each of the factors based on their suitability for urban growth. For suitability analysis using GIS-AHP, it is important to assign scores to each of the factors based on their suitability for urban growth. To do this, a pairwise comparison matrix using Saaty's nine-level scale for identifying relative weights was used. The calculation of factor weights was applied after the formation of the pairwise comparison matrix. The next step involves the computation of Consistency Ratio (CR), which is used to measure the consistency between the experts' opinions. The acceptable Consistency Ratio (CR) should be $\mathrm{CR}<0.10$, which refers to a reasonable level of consistency in the pairwise comparisons. In contrast, $C R>0.10$ refers to ratio values that are indicative of inconsistent judgments [6].

AHP has been integrated with GIS tools to identify the importance of the criteria used and to calculate weights by using a scale of importance and the opinion of experts. AHP is commonly applied to identify the weights of influencing factors on urban growth on the basis of the analysis functions of GIS. AHP is also a structured approach that can be used for complex cases of making decisions that include competing criteria. The weights of factors in AHP can commonly be identified by using driven knowledge and driven data. The weights of factors can also be calculated by using a questionnaire given to specialists who have considerable experience in the field of urban growth and can then be determined by 
using pairwise comparison method to measure their relative importance vis-à-vis one another [6]. The results confirm that the GIS-AHP model is a useful technique for environmental management and urban planning [6].

\subsection{Cellular Automata CA-Markov Chain MC Model-AHP}

The creation of an accurate simulation of future urban growth is considered one of the most important challenges in urban studies that involve spatial modeling. The purpose of this study is to improve the simulation capability of an integrated CA-Markov Chain (CA-MC) model using CA-MC based on the Analytical Hierarchy Process (AHP) and CA-MC based on Frequency Ratio (FR), both applied in Seremban, Malaysia, as well as to compare the performance and accuracy between the traditional and hybrid models. Various physical, socio-economic, utilities, and environmental criteria were used as predictors, including elevation, slope, soil texture, population density, distance to commercial area, distance to educational area, distance to residential area, distance to industrial area, distance to roads, distance to highway, distance to railway, distance to power line, distance to stream, and land cover [9].

\subsection{Cellular Automata CA-Markov Chain MC Model-GIS-RS}

Currently, various types of models and methods within the RS and GIS techniques are generally being employed for modeling urban growth trends and in the simulation of land use changes [9]. There are studies that have used traditional models, which depend on the assessment of the dynamic growth of urban areas, such as the Cellular Automata (CA) models [9]. Some of these studies have also relied on quantitative models, such as Logistic Regression (LR), for simulation and prediction [9]. Other studies have relied on the incorporation of various types of models, such as the CA and the Markov Chain (MC) models, to achieve accurate and realistic results [9]. The modeling of urban growth patterns based on RS and GIS techniques is conducted to understand the spatial process for urban movement within a specific time toward the creation of future policies of sustainable development [9]. The Cellular Automata (CA) model has an open structure and can be integrated with other models to simulate and predict urban growth patterns [9]. Flexibilities, clarity, and the capability to integrate dynamic and spatio-temporal aspects of the urbanization processes, as well as the capability to model complex dynamic systems are major reasons for the widespread utilization of the CA model in the prediction and simulation of urban expansion trends and future land use and cover changes in recent years [9].

\subsection{Cellular Automata CA-Markov Chain MC Model-Logistic Regression}

The significance of using the integrated CA-Markov Chain model is that it plays an important role in modeling urban growth, especially in developing countries, which have different urban features. However, it is important to assert that the 
urban growth driving forces such as physical, environment, socioeconomic, and utilities forces should be applied in the prediction process of the CA-Markov chain model, so as to obtain a better understanding of the change in urban growth patterns. For this purpose, the CA-Markov chain model should be integrated with other models such as the Analytic Hierarchy Process (AHP), Frequency ratio (FR), and logistic regression (LR) models to further improve its capability [9]. CA-Markov is an open structure spatial model which can be used to improve the capability of urban growth simulation [9]. In [9] study, the CA-Markov model was applied to simulate and predict future urban growth in study area. The optimal CA transition rules for the model were computed using the appropriate iteration numbers (i.e. 10, 40, and 60) together with a contiguity filter of $5 \times 5$ because the highest values of accuracy were obtained using these iteration numbers and the chosen contiguity filter. After that, these iteration numbers and the contiguity filter were used to predict land use in 2020 and 2030. According to the successful model validation, the future urban and non-urban land-use maps of 2020 and 2030 were generated using the actual map of 2000 and 2010, respectively [9].

A Markov-logistic-CA model was developed to simulate the LUC processes of an urban system. This model is a dynamic urban LUC model that was created by incorporating an $\mathrm{MC}$ and neighborhood interactions. Three types of driving forces (influence of transportation, zoning impacts, and physical suitability) were classified through the socioeconomic dataset and converted into unrelated variables using principle component analysis (PCA). Their influences were later measured through logistic regression models. Transfer potentials for each cell were calculated using the MCE method and LUC according to the allocation rule, to satisfy the balance between supply and demand for each land use in each year of simulation. Recently, a combination of empirical estimation and dynamic simulation has been widely adopted in urban modeling studies.

CA is a typical representative dynamic simulation model. In terms of LUC, CA models simulate dynamic processes based on the assumption that the land use of the central cell changes through the interaction of land uses in the neighborhood, and can identify how cities have developed by incorporating various social and economic factors into transition rules. Several statistical methods, including regression, Markov chain (MC), and classification algorithms based on machine learning theory, have been coupled with CA models to simulate the dynamic process of urban growth applied a first-order MC to a CA model to predict complex LUC under continuous urbanization. For larger areas, with multiple administrative districts and complex urban land use patterns, further study is needed to improve model performance. [7]. The CA-Markov model was integrated with AHP, and then integrated with FR to improve its capability in simulating and predicting urban growth. The inclusion of driving forces of urban growth in the simulation process is the main idea for integrating the CA-Markov model with the AHP and FR models [9]. 


\section{Results Discussion and Recommendations}

\subsection{Discussion}

The results of this study confirm that a realistic simulation should include realistic driving forces of urban growth patterns, which take into account the international, national, and local scales. These driving forces should include socio-economic, spatiotemporal, quantitative, and dynamic aspects. However, the findings of the study show that identifying the significant influencing factors of urban growth trends in the study area is not enough to generate a perfect simulation process; [9]. Moreover, the most important result came by combining two or more than two techniques and models to assure that the simulation or prediction models can give real and right approaches. Most researches focused on combining specific techniques with models such as Cellular Automata CA-Markov Chain MC model-Logistic regression or Cellular Automata CA-Markov Chain MC model or GIS-MCDM or GIS Based AHP etc.

\subsection{Recommendations}

As a recommendation, researchers might have to focus on taking a definite process as Figure 4 and Figure 5 show. This process designed to get better results started with defining objectives until finding best practice to use. According to Figure 3, and Tables 1-4, the study of urban growth should take a specific flow starting with the fundamental needs for any research or study which is theoretical \& technical framework followed by study objectives. After that, then choose the most relative and best practice data and factors to the best combination of models for more specific results. Besides, Figure 4 represents the factors, data which work together well with model combination. Generally speaking, Figure 5 shows the whole process to study urban growth, but, Figure 5 illustrates

\section{Best practice of data and factors \\ factors:}

- Value of the urban expansion pattern (Elevation, slope, soil texture, population density, distance to (road, highways, railways, power lines, streams, distance to water, distance to airport, industrial, residential, commercial, educational areas)

- Probability of:(organic growth - spontaneous growth - new spreading center)

- Intersection between the buffer zone and patches or between the buffer zone and vacant areas

- Land use and land cover change

Data:

- Land use and land cover change maps

- Land use change index.

- $\quad$ Geospatial data set (land sat thematic mapper- land sat enhanced thematic mapper) images

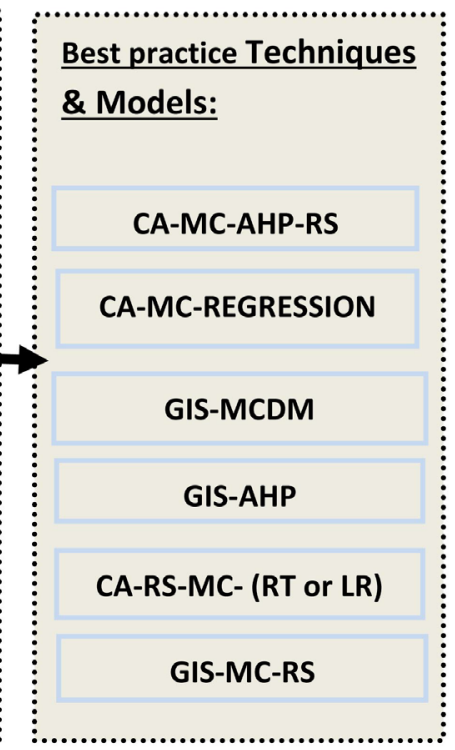

Figure 4. Illustrates best choosing of urban growth best practice of data, factors, techniques \& models. 


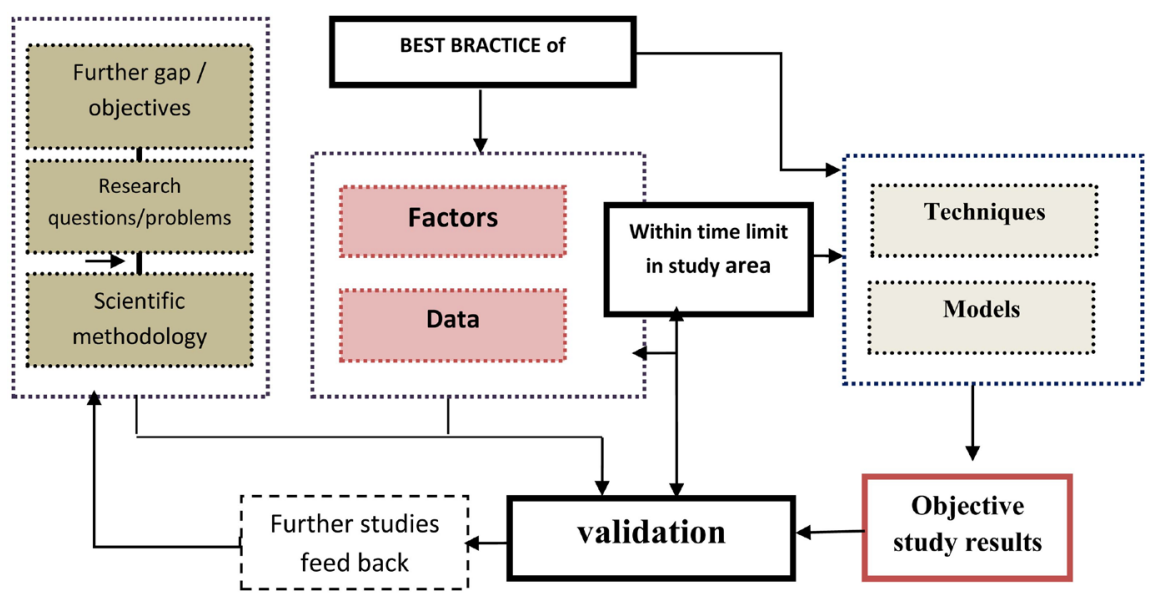

Figure 5. Illustrates best approach for each study structure of urban growth model process.

the time limit which generates the validation of the whole study and may define the furthered gabs according to study feedback.

\section{Acknowledgements}

Financial support for this study was provided by a grant from the Ministry of physical planning and urban development. The authors wish to thank everyone who gave advices and suggestions on preparing the manuscript.

\section{Conflicts of Interest}

The authors declare no conflicts of interest.

\section{References}

[1] Bharath, H.A., Chandan, M.C., Vinay, S. and Ramachandra, T.V. (2018) Modelling Urban Dynamics in Rapidly Urbanising Indian Cities. The Egyptian Journal of Remote Sensing and Space Science, 21, 201-210.

https://doi.org/10.1016/j.ejrs.2017.08.002

[2] Castells-Quintana, D. (2017) Malthus Living in a Slum: Urban Concentration, Infrastructure and Economic Growth. Journal of Urban Economics, 98, 158-173. https://doi.org/10.1016/j.jue.2016.02.003

[3] Wang, C.H. and Wang, Z.-H. (2017) Projecting Population Growth as a Dynamic Measure of Regional Urban Warming. Sustainable Cities and Society, 32, 357-365. https://doi.org/10.1016/j.scs.2017.04.010

[4] Sathish Kumar, D., Arya, D.S. and Vojinovic, Z. (2013) Modeling of Urban Growth Dynamics and Its Impact on Surface Runoff Characteristics. Computers, Environment and Urban Systems, 41, 124-135.

https://doi.org/10.1016/j.compenvurbsys.2013.05.004

[5] Long, Y., Han, H.Y., Tu, Y.C. and Shu, X.F. (2015) Evaluating the Effectiveness of Urban Growth Boundaries Using Human Mobility and Activity Records. Cities, 46, 76-84. https://doi.org/10.1016/j.cities.2015.05.001

[6] Aburas, M.M., Abdullah, S.H.O., Ramli, M.F. and Asha'ari, Z.H. (2017) Land Suitability Analysis of Urban Growth in Seremban Malaysia, Using GIS Based Analytical 
Hierarchy Process. Procedia Engineering, 198, 1128-1136.

https://doi.org/10.1016/j.proeng.2017.07.155

[7] Han, Y. and Jia, H.F. (2017) Simulating the Spatial Dynamics of Urban Growth with an Integrated Modeling Approach: A Case Study of Foshan, China. Ecological Modelling, 353, 107-116. https://doi.org/10.1016/j.ecolmodel.2016.04.005

[8] Liu, Y.L., He, Q.S., Tan, R.H., Liu, Y.F. and Yin, C.H. (2016) Modeling Different Urban Growth Patterns Based on the Evolution of Urban Form: A Case Study from Huangpi, Central China. Applied Geography, 66, 109-118. https://doi.org/10.1016/j.apgeog.2015.11.012

[9] Milad Aburas, M., Ho, Y.-M., Firuz Ramli, M. and Ash'aari, Z.H. (2017) Improving the Capability of an Integrated CA-Markov Model to Simulate Spatio-Temporal Urban Growth Trends Using an Analytical Hierarchy Process and Frequency Ratio. International Journal of Applied Earth Observation and Geoinformation, 59, 65-78. https://doi.org/10.1016/j.jag.2017.03.006

[10] Milad Aburas, M., Ho, Y.-M., Firuz Ramli, M. and Ash'aari, Z.H. (2016) The Simulation and Prediction of Spatio-Temporal Urban Growth Trends Using Cellular Automata Models: A Review. International Journal of Applied Earth Observation and Geoinformation, 52, 380-389. https://doi.org/10.1016/j.jag.2016.07.007

[11] Abhishek, N., Mamata, J. and Biswajit, M. (2017) Urban Growth in Indian Cities: Are the Driving Forces Really Changing? Habitat International, 69, 48-57. https://doi.org/10.1016/j.habitatint.2017.08.002

[12] Jat, M.K., Mahender C. and Ankita S. (2017) Application of Geo-Spatial Techniques and Cellular Automata for Modelling Urban Growth of a Heterogeneous Urban Fringe. The Egyptian Journal of Remote Sensing and Space Science, 20, 223-241. https://doi.org/10.1016/j.ejrs.2017.02.002

[13] Zhao, C.H., Jensen, J. and Zhan, B. (2017) A Comparison of Urban Growth and Their Influencing Factors of Two Border Cities: Laredo in the US and Nuevo Laredo in Mexico. Applied Geography, 79, 223-234. https://doi.org/10.1016/j.apgeog.2016.12.017

[14] Li, X.C., Gong, P., Yu, L. and Hu, T.Y. (2017) A Segment Derived Patch-Based Logistic Cellular Automata for Urban Growth Modeling with Heuristic Rules. Computers, Environment and Urban Systems, 65, 140-149. https://doi.org/10.1016/j.compenvurbsys.2017.06.001

[15] El Garouani, A., Mulla, D.J., El Garouani, S. and Knight, J. (2017) Analysis of Urban Growth and Sprawl from Remote Sensing Data: Case of Fez, Morocco. International Journal of Sustainable Built Environment, 6, 160-169. https://doi.org/10.1016/j.ijsbe.2017.02.003

[16] Ströbele, M. and Marcel H. (2017) Are Suburbs Perceived as Rural Villages? Landscape-Related Residential Preferences in Switzerland. Landscape and Urban Planning, 163, 67-79. https://doi.org/10.1016/j.landurbplan.2017.02.015

[17] Smith, J.W., Smart, L.S., Dorning, M.A., Nicole Dupéy, L., Méley, A. and Meentemeyer, R.K. (2017) Bayesian Methods to Estimate Urban Growth Potential. Landscape and Urban Planning, 163, 1-16. https://doi.org/10.1016/j.landurbplan.2017.03.004

[18] Sharifi, A., Chiba, Y., Okamoto, K., Yokoyama, S. and Murayama, A. (2014) Can Master Planning Control and Regulate Urban Growth in Vientiane, Laos? Landscape and Urban Planning, 131, 1-13. https://doi.org/10.1016/j.landurbplan.2014.07.014

[19] Chen, Y.M., Li, X., Liu, X.P., Ai, B. and Li, S.Y. (2016) Capturing the Varying Ef- 
fects of Driving Forces over Time for the Simulation of Urban Growth by Using Survival Analysis and Cellular Automata. Landscape and Urban Planning, 152, 59-71. https://doi.org/10.1016/j.landurbplan.2016.03.011

[20] Süha, B., Akın, A. and Clarke, K.C. (2016) Cellular Automata Modeling Approaches to Forecast Urban Growth for Adana, Turkey: A Comparative Approach. Landscape and Urban Planning, 153, 11-27. https://doi.org/10.1016/j.landurbplan.2016.04.017

[21] Issahaka, F. and Kemp, J. (2016) Characterising Urban Growth in Tamale, Ghana: An Analysis of Urban Governance Response in Infrastructure and Service Provision. Habitat International, 56, 109-123. https://doi.org/10.1016/j.habitatint.2016.05.002

[22] Shi, Y.Q., Sun, X., Zhu, X.D., Li, Y.F. and Mei, L.Y. (2012) Characterizing Growth Types and Analyzing Growth Density Distribution in Response to Urban Growth Patterns in Peri-Urban Areas of Lianyungang City. Landscape and Urban Planning, 105, 425-433.https://doi.org/10.1016/j.landurbplan.2012.01.017

[23] Houet, T., Marchadier, C., Bretagne, G., Moine, M.P., Aguejdad, R., Viguié, V., Bonhomme, M., Lemonsu, A., Avner, P., Hidalgo, J. and Masson, V. (2016) Combining Narratives and Modelling Approaches to Simulate Fine Scale and Long-Term Urban Growth Scenarios for Climate Adaptation. Environmental Modelling \& Software, 86, 1-13. https://doi.org/10.1016/j.envsoft.2016.09.010

[24] Lei, W., Potter, C. and Li, Z.G. (2014) Crisis-Induced Reform, State-Market Relations, and Entrepreneurial Urban Growth in China. Habitat International, 41, 50-57. https://doi.org/10.1016/j.habitatint.2013.06.008

[25] Ma, S.F., Li, X. and Cai, Y.M. (2017) Delimiting the Urban Growth Boundaries with a Modified Ant Colony Optimization Model. Computers, Environment and Urban Systems, 62, 146-155. https://doi.org/10.1016/j.compenvurbsys.2016.11.004

[26] Aguilera-Benavente, F., Botequilha-Leitão, A. and Díaz-Varela. E. (2014) Detecting Multi-Scale Urban Growth Patterns and Processes in the Algarve Region (Southern Portugal). Applied Geography, 53, 234-245. https://doi.org/10.1016/j.apgeog.2014.06.019

[27] Nassar, A.K., Alan Blackburn, G. and Duncan Whyatt, J. (2014) Developing the Desert: The Pace and Process of Urban Growth in Dubai. Computers, Environment and Urban Systems, 45, 50-62. https://doi.org/10.1016/j.compenvurbsys.2014.02.005

[28] Wang, W., Zhang, X.L., Wu, Y.Z., Zhou, L. and Skitmore, M. (2017) Development Priority Zoning in China and Its Impact on Urban Growth Management Strategy. Cities, 62, 1-9. https://doi.org/10.1016/j.cities.2016.11.009

[29] He, Q.S., Song, Y., Liu, Y.L. and Yin, C.H. (2017) Diffusion or Coalescence? Urban Growth Pattern and Change in 363 Chinese Cities from 1995 to 2015. Sustainable Cities and Society, 35, 729-739. https://doi.org/10.1016/j.scs.2017.08.033

[30] Alhowaish, A.K. (2015) Eighty Years of Urban Growth and Socioeconomic Trends in Dammam Metropolitan Area, Saudi Arabia. Habitat International, 50, 90-98. https://doi.org/10.1016/j.habitatint.2015.08.019

[31] Zambon, I., Serra, P., Grigoriadis, E., Carlucci, M. and Salvati, L. (2017) Emerging Urban Centrality: An Entropy-Based Indicator of Polycentric Development and Economic Growth. Land Use Policy, 68, 365-371. https://doi.org/10.1016/j.landusepol.2017.07.063

[32] Jin, X.B., Long, Y., Sun, W., Lu, Y.Y., Yang, X.H. and Tang, J.X. (2017) Evaluating Cities' Vitality and Identifying Ghost Cities in China with Emerging Geographical Data. Cities, 63, 98-109. https://doi.org/10.1016/j.cities.2017.01.002

[33] Agostinho, F., Sevegnani, F., Almeida, C.M.V.B. and Giannetti, B.F. (2018) Explor- 
ing the Potentialities of Emerge Accounting in Studying the Limits to Growth of Urban Systems. Ecological Indicators, 94, 4-12. https://doi.org/10.1016/j.ecolind.2016.05.007

[34] Barreira-González, P., Gómez-Delgado, M. and Aguilera-Benavente, F. (2015) From Raster to Vector Cellular Automata Models: A New Approach to Simulate Urban Growth with the Help of Graph Theory. Computers, Environment and Urban Systems, 54, 119-131. https://doi.org/10.1016/j.compenvurbsys.2015.07.004

[35] Ahmed, S. and Bramley, G. (2015) How Will Dhaka Grow Spatially in Future? Modelling Its Urban Growth with a Near-Future Planning Scenario Perspective. International Journal of Sustainable Built Environment, 4, 359-377. https://doi.org/10.1016/j.ijsbe.2015.07.003

[36] Kim, H.S, Kim, Y.-K., Song, S.-K. and Lee, H.W. (2016) Impact of Future Urban Growth on Regional Climate Changes in the Seoul Metropolitan Area, Korea. Science of the Total Environment, 571, 355-363. https://doi.org/10.1016/j.scitotenv.2016.05.046

[37] Martín, J.A.R., De Arana, C., Ramos-Miras, J.J., Gil, C. and Boluda, R. (2015) Impact of 70 Years' Urban Growth Associated with Heavy Metal Pollution. Environmental Pollution, 196, 156-163. https://doi.org/10.1016/j.envpol.2014.10.014

[38] Shafizadeh-Moghadam, H., Tayyebi, A., Ahmadlou, M., Reza Delavar, M. and Hasanlou, M. (2017) Integration of Genetic Algorithm and Multiple Kernel Support Vector Regression for Modeling Urban Growth. Computers, Environment and Urban Systems, 65, 28-40.https://doi.org/10.1016/j.compenvurbsys.2017.04.011

[39] Alnsour, J.A. (2016) Managing Urban Growth in the City of Amman, Jordan. Cities, 50, 93-99. https://doi.org/10.1016/j.cities.2015.08.011

[40] Yi, K.P., Zeng, Y. and Wu, B.F. (2016) Mapping and Evaluation the Process, Pattern and Potential of Urban Growth in China. Applied Geography, 71, 44-55. https://doi.org/10.1016/j.apgeog.2016.04.011

[41] Mustafa, A., Saadi, I., Cools, M. and Teller, J. (2014) Measuring the Effect of Stochastic Perturbation Component in Cellular Automata Urban Growth Model. Procedia Environmental Sciences, 22, 156-168. https://doi.org/10.1016/j.proenv.2014.11.016

[42] He, Q.S., Tan, R.H., Gao, Y., Zhang, M.K., Xie, P. and Liu, Y.L. (2018) Modeling Urban Growth Boundary Based on the Evaluation of the Extension Potential: A Case Study of Wuhan City in China. Habitat International, 72, 57-65. https://doi.org/10.1016/j.habitatint.2016.11.006

[43] Achmad, A., Hasyim, S., Dahlan, B. and Aulia, D.N. (2015) Modeling of Urban Growth in Tsunami-Prone City Using Logistic Regression: Analysis of Banda Aceh, Indonesia. Applied Geography, 62, 237-246. https://doi.org/10.1016/j.apgeog.2015.05.001

[44] Linard, C., Tatem, A.J. and Gilbert, M. (2013) Modelling Spatial Patterns of Urban Growth in Africa. Applied Geography, 44, 23-32. https://doi.org/10.1016/j.apgeog.2013.07.009

[45] Perotti, L., Antonella Dino, G., Lasagna, M., Moussa, K., Spadafora, F., Yadji, G., Tankari Dan-Badjo, A. and De Luca, D.A. (2016) Monitoring of Urban Growth and Its Related Environmental Impacts: Niamey Case Study (Niger). Energy Procedia, 97, 37-43. https://doi.org/10.1016/j.egypro.2016.10.014

[46] Rizk Hegazy, I. and Rashed Kaloop, M. (2015) Monitoring Urban Growth and Land Use Change Detection with GIS and Remote Sensing Techniques in Daqahlia Governorat Egypt. International Journal of Sustainable Built Environment, 4, 117-124. 
https://doi.org/10.1016/j.ijsbe.2015.02.005

[47] Pribadi, D.O., Zasada, I., Müller, K. and Pauleit, S. (2017) Multifunctional Adaption of Farmers as Response to Urban Growth in the Jabodetabek Metropolitan Area, Indonesia. Journal of Rural Studies, 55, 100-111.

https://doi.org/10.1016/j.jrurstud.2017.08.001

[48] Brunner, I. and Made, I.M. (2016) Prediction of Urban Growth Using the Bucket Model. Procedia-Social and Behavioral Sciences, 227, 3-10. https://doi.org/10.1016/j.sbspro.2016.06.036

[49] Van de Voorde, T., van der Kwast, J., Poelmans, L., Canters, F., Binard, M., Cornet, Y., et al. (2016) Projecting Alternative Urban Growth Patterns: The Development and Application of a Remote Sensing Assisted Calibration Framework for the Greater Dublin Area. Ecological indicators, 60, 1056-1069.

https://doi.org/10.1016/j.ecolind.2015.08.035

[50] Ali Noorhosseini, S., Sadegh Allahyari, M., Damalas, C.A. and Siavash Moghaddam, S. (2017) RETRACTED: Public Environmental Awareness of Water Pollution from Urban Growth: The Case of Zarjub and Goharrud Rivers in Rasht, Iran. Science of the Total Environment, 599-600, 2019-2025.

https://doi.org/10.1016/j.scitotenv.2017.05.128

[51] Ogle, J., Delparte, D. and Sanger, H. (2017) Quantifying the Sustainability of Urban Growth and Form through Time: An Algorithmic Analysis of a City's Development. Applied Geography, 88, 1-14. https://doi.org/10.1016/j.apgeog.2017.08.016

[52] Santos, D.S., Mansur, K.L., Gonçalves, J.B., Arruda, E.R. and Manosso, F.C. (2017) Quantitative Assessment of Geodiversity and Urban Growth Impacts in Armação dos Búzios, Rio de Janeiro, Brazil. Applied Geography, 85, 184-195. https://doi.org/10.1016/j.apgeog.2017.03.009

[53] García-Ayllón, S. (2016) Rapid Development as a Factor of Imbalance in Urban Growth of Cities in Latin America: A Perspective Based on Territorial Indicators. Habitat International, 58, 127-142. https://doi.org/10.1016/j.habitatint.2016.10.005

[54] Mushore, T.D., Odindi, J., Dube, T., Nyasha Matongera, T. and Mutanga, O. (2017) Remote Sensing Applications in Monitoring Urban Growth Impacts on in-and-out Door Thermal Conditions: A Review. Remote Sensing Applications. Society and Environment, 8, 83-93. https://doi.org/10.1016/j.rsase.2017.08.001

[55] Holst, C.C., Chan, J.C.L. and Tam, C.-Y. (2017) Sensitivity of Precipitation Statistics to Urban Growth in a Subtropical Coastal Megacity Cluster. Journal of Environmental Sciences, 59, 6-12. https://doi.org/10.1016/j.jes.2017.01.004

[56] Guan, C.H. and Rowe, P.G. (2016) Should Big Cities Grow? Scenario-Based Cellular Automata Urban Growth Modeling and Policy Applications. Journal of Urban Management, 5, 65-78. https://doi.org/10.1016/j.jum.2017.01.002

[57] Novin, M.S. and Khosravi, F. (2017) Simulating Urban Growth by Emphasis on Connective Routes Network (Case Study: Bojnourd City). The Egyptian Journal of Remote Sensing and Space Science, 20, 31-40.

https://doi.org/10.1016/j.ejrs.2016.10.001

[58] Aljoufie, M., Zuidgeest, M., Brussel, M. and van Maarseveen, M. (2013) Spatial-Temporal Analysis of Urban Growth and Transportation in Jeddah City, Saudi Arabia. Cities, 31, 57-68. https://doi.org/10.1016/j.cities.2012.04.008

[59] Pickens, B.A., Marcus, J.F., Carpenter, J.P., Anderson, S., Taillie, P.J. and Collazo, J.A. (2017) The Effect of Urban Growth on Landscape-Scale Restoration for a Fire-Dependent Songbird. Journal of Environmental Management, 191, 105-115. https://doi.org/10.1016/j.jenvman.2017.01.005 
[60] Benedek, J. (2016) The Role of Urban Growth Poles in Regional Policy: The Romanian Case. Procedia-Social and Behavioral Sciences, 223, 285-290. https://doi.org/10.1016/j.sbspro.2016.05.368

[61] Tan, M.H. (2017) Uneven Growth of Urban Clusters in Megaregions and Its Policy Implications for New Urbanization in China. Land Use Policy, 66, 72-79. https://doi.org/10.1016/j.landusepol.2017.04.032

[62] Chitrakar, R.M., Baker, D.C. and Guaralda, M. (2016) Urban Growth and Development of Contemporary Neighbourhood Public Space in Kathmandu Valley, Nepal. Habitat International, 53, 30-38. https://doi.org/10.1016/j.habitatint.2015.11.006

[63] Tan, R.H., Liu, Y.L., Liu, Y.F., He, Q.S., Ming, L.C. and Tang, S.H. (2014) Urban Growth and Its Determinants across the Wuhan Urban Agglomeration, Central China. Habitat International, 44, 268-281. https://doi.org/10.1016/j.habitatint.2014.07.005

[64] Dos Santos, S., Adams, E.A., Neville, G., Wada, Y., de Sherbinin, A., Mullin Bernhardt, E. and Adamo, S.B. (2017) Urban Growth and Water Access in Sub-Saharan Africa: Progress, Challenges, and Emerging Research Directions. Science of the Total Environment, 607-608, 497-508. https://doi.org/10.1016/j.scitotenv.2017.06.157

[65] Barbier, E.B. and Chaudhry, A.M. (2014) Urban Growth and Water. Water Resources and Economics, 6, 1-17. https://doi.org/10.1016/j.wre.2014.05.005

[66] Li, X.C. and Gong, P. (2016) Urban Growth Models: Progress and Perspective. Science Bulletin, 61, 1637-1650. https://doi.org/10.1007/s11434-016-1111-1

[67] Du, R. (2016) Urban Growth: Changes, Management, and Problems in Large Cities of Southeast China. Frontiers of Architectural Research, 5, 290-300. https://doi.org/10.1016/j.foar.2016.04.002

[68] Wei, Y.H.D., Li, H. and Yue, W.Z. (2017) Urban Land Expansion and Regional Inequality in Transitional China. Landscape and Urban Planning, 163, 17-31. https://doi.org/10.1016/j.landurbplan.2017.02.019

[69] Wu, Y.Z., Luo, J.J., Zhang, X.L. and Skitmore, M. (2016) Urban Growth Dilemmas and Solutions in China: Looking Forward to 2030. Habitat International, 56, 42-51. https://doi.org/10.1016/j.habitatint.2016.04.004

[70] Liu, J.J., Nijkamp, P. and Lin. D.R. (2017) Urban-Rural Imbalance and Tourism-Led Growth in China. Annals of Tourism Research, 64, 24-36.

https://doi.org/10.1016/j.annals.2017.02.005 